\title{
Centre for European Studies (CES)
}

\author{
University of Twente \\ The Netherlands
}

CES Working Paper

No. $1 / 04$

RAMSEs A. Wessel

The Multilevel Constitution of European Foreign Relations

$<w w w . b b t . u t w e n t e . n l / c e s>$

All rights reserved.

No part of this paper may be reproduced in any form without permission of the author. 


\title{
The Multilevel Constitution of European Foreign Relations
}

\author{
"[T]he problem of establishing a perfect civil constitution \\ is subordinate to the problem of a law-governed \\ external relationship with other states, \\ and cannot be solved unless the latter is also solved." \\ (Immanuel Kant, Idea for a Universal History with \\ a Cosmopolitan Purpose, 1784) ${ }^{1}$
}

RAMSEs A. WESSEL

Associate Professor of International and European Law, Centre for European Studies, University of Twente (R.A.Wessel@utwente.nl)

\section{Introduction}

My answer to the question "Does the European Union need a Constitution?" ${ }^{2}$ usually reads something like: "What about the Treaty on European Union?". For those active in international institutional law, the constituent treaty of an international organisation - a label that still fits the European Union - forms the 'constitution' of the organisation, defining the scope and content of the legal order created by it. This definition of a constitution comes close to a classic one presented by Verdross - one of the godfathers of 'international constitutional law' - in 1926: "Errichtung einer dauerhaften und stabilen Grundordnung, welche eine Rechtsgemeinschaft errichtet und institutionell ausstattet". ${ }^{3}$ A constitution of an international organisation thus, primarily, defines an institutional framework in which competences are being divided among institutions in a way that cannot be changed over night. The word 'Rechtsgemeinschaft', however, seems to refer to a community based on the rule of law, with a judiciary to supervise the functioning of the agreed procedures as well as an inclusion of those that are 'governed' by the international organisation, member states and - less often - citizens. ${ }^{4}$ It is in particular this latter notion that is usually regarded to give some substance to the primarily rather formal concept of constitution in international law.

These two approaches to the notion of 'constitution' as applied to international organisations the 'neutral' definition as a legal system vis-à-vis the more value-oriented one - form the basis of the literature on the constitutionalisation of Europe. Whereas the term 'constitutional structure' is often used to analyse the competences of the institutions and the relationship between the organisation and its member states, ${ }^{5}$ a more substantive approach focuses on the way in which constitutional elements

1 I. Kant, Political Writings, edited by H. Reiss, 1991, at 47.

2 See for instance D. Grimm, 'Does Europe Need an Constitution', ELJ, 1995, 282 and the comments by J. Habermas, 'Remarks on Dieter Grimm's 'Does Europe Need a Constitution?', ELJ, 1995, 303. And, more recently: J. Habermas, 'So, Why Does Europe Need a Constitution?' (Hamburg Lecture of 26 June 2001, available at http://www.iue.it/RSC/EU/Reform02(uk).pdf.

3 A. Verdross, Die Verfassung der Völkerrechtsgemeinschaft, Wien/Berlin: Springer Verlag, 1926, Vorwort.

4 Cf. Case 294/83, Les Verts v. Parliament, [1986] ECR 1339, para. 23, in which the ECJ already referred to the EC Treaty as "the constitutional charter of a Community based on the rule of law". See also K. Lenaerts and M. Desomer, 'New Models of Constitution-Making in Europe: The Quest for Legitimacy', CML Rev, 2002, pp. 1217-1253. Although Verdross himself seems to approach the concept from a more positivist angle: "Rechtsgemeinschaft ist nur jene Gemeinschaft, die durch einen Kreis von Rechtsnormen als Einheit erfaßt und dadurch von anderen abgegrenzt wird" (p. 4). In that sense it should probably not be translated as 'legal community', but comes closer to 'legal system'.

5 An example of this approach can be found in G. De Búrca, 'The Institutional Development of the EU: A Constitutional Analysis', in P. Craig and G. De Búrca, The Evolution of EU Law, Oxford University Press, 1999, 55-82. 
could be introduced to expose European governance to the checks and balances that we are familiar with in our own national legal systems. It is obvious that this latter approach is often far from 'valuefree': much of the debate not only concerns the question of how constitutional elements are to be brought into the EU legal order, but many observers are even sincerely concerned about the lack of these elements in an international organisation that increasingly starts to look like a state. ${ }^{6}$

An approach that seems to fit in between these two perspectives takes the more neutral definition of a constitution as a starting point, without neglecting the fact that the European Union indeed is a very special organisation the constituent treaty of which not only concerns the "High Contracting Parties', but also the private persons and entities within the member states. In that sense it is the prime instance of what Ige Dekker and I recently coined 'integration organisations'. An essential feature of these organisations is that competences are transferred from the member states to the organisation or that new competences for the organisation are created, through which it becomes competent (sometimes exclusively, but often in competition) to set rules with direct effects within the legal orders of the member states. ${ }^{7}$

Although states do not cease to exist by becoming a member of an international (integration) organisation, it becomes difficult to regard their national legal order as existing in complete isolation from the legal order of the organisation. The 'constitutional setting' in which they operate may for a great deal already depend on general international law, and at least clearly includes the arrangements they agreed on in the framework of an international organisation. And, vice versa, the international organisation has to deal with the Janus-faced identity of member states: on the one hand member states are constituent parts of the international organisation they created among themselves; on the other hand the states are the counterparts of the same international organisation in the sense that both occupy independent positions within the international legal order and even have obligations towards each other. This relationship is indeed somewhat schizophrenic, as one scholar once observed. $^{8}$

In that respect, Weiler's remark that "Constitutionalism, more than anything else, is what differentiates the Community from other transnational systems and, with the Union from the other "pillars"' since "the Community behaves as if its founding document were not a treaty governed by international law but [...] a constitutional charter governed by a form of constitutional law" seems to ignore the fact that 'constitutionalisation' as a process powered by the 'Eigendynamik' of the legal orders of international organisation is not exclusively to be found in the Community. ${ }^{10}$ There are good

6 An example related to the subject of the present paper is E.-U. Petersmann, 'The Moral Foundations of the European Union's Foreign Policy Constitution: Defining 'European Identity' and 'Community Interests' for the Benefit of EU Citizens', Aussenwirtschaft, 1996, Heft II, pp. 151-176.

7 I.F. Dekker and R.A. Wessel, 'Governance by International Organisations: Rethinking the Normative Force of International Decisions', in I.F. Dekker and W. Werner (Eds.), Challenges of Governance: Collected papers on the Methodology and Subjects of International Law and International Relations, The Hague: Kluwer Law International (2003, forthcoming). Cf. also Pernice's remarks regarding the direct relations between the people and the supranational institutions, through directly applicable rights and obligations for individuals: "Although the form of an international treaty is maintained, such treaties can be regarded [...] as a common exercise of constitution-making power by the peoples of the participating State". I. Pernice, 'Multilevel Constitutionalism and the Treaty of Amsterdam: European Constitution-Making Revisited?', CML Rev., 1999, 703-750, at 717.

8 J. Klabbers, 'The Changing Image of International Organizations', in: J.-M. Coicund and V. Heishanen (Eds.), The Legitimacy of International Organizations, Tokyo: UN Univesrity Press, 2001, pp. 221-255 at 227.

9 J. Weiler, 'Introduction: The Reformation of European Constitutionalism' in his The Constitution of Europe, Cambridge University Press, 1999, p. 221.

10 This type of constitutional approach is often used by others. See for instance W. Sauter, The Economic Constitution of the European Union', Columbia Journal of European Law, Winter/Spring, 1998; or B. Fassbender, 'The United Nations Charter as Constitution of the International Community', Columbia Journal of Transnational Law, 1998, pp. 529-619; J. Weiler, 'The Constitution of the Common market Place' and F. Snyder, 'Eмu Revisited: Are We Making a Constitution? What Constitution are We Making?', both in Craig and De Búrca (1998), op. cit. Cf. also the concept of 'vertical constitutionalism' used by Joerges in relation to the economic constitution. Chr. Joerges, 'The Law in the Process of Constitutionalizing Europe', paper presented at the ARENA Conference on Democracy and European Governance, March 4-5, 2002 (available at http://www.arena.uio.no/events/Conference2002/documents/Joerges.doc). 
reasons to apply the same concept at least to the other 'pillars' of the Union, ${ }^{11}$ but maybe even to other 'integration-organisations' in the sense defined above. 'Constitutional sedimentation', as one observer has called it, is a much more general phenomenon. ${ }^{12}$ Once a treaty relationship between states is converted into a new 'legal institution"13 through an act of legal personification, by which an 'association of states' is turned into a new separate legal entity, it becomes possible to see a 'will' of the new entity as opposed to the (collective) will of the original parties to the deal. This volonté distincte may be congruent to the collective will of the member states, but it may very well take its own course. The notion of 'constitution' as used in the present paper thus owes its distinguishing characteristic to the fact that it does not merely reflect the treaty-relationship between the states of an international organisation (although it is the result of this contractual process), but that it also encompasses the relationship between the newly created legal order of the organisation and the national orders of the member states, while including the legal subjects within the latter. The 'european community' (no capitals) is thus understood to comprise both the states and their citizens as well as the 'supranational' institution created by them. ${ }^{14}$

This chapter, indeed, deals with the European Union, and more particularly with the external relations of the Union. While the economic external relations will occasionally be referred to, the main focus will be on the external political ('foreign affairs') relations. It is in this area in particular that the complex relationship between the Union and its member states presents itself in its full dimension. ${ }^{15}$ The purpose of this contribution is to present a meaningful way to analyse the constitutionalisation of the external relations of the Union, while acknowledging the important role of the member states in this area. After all, the Treaty provides that the Union "shall assert its identity on the international scene, in particular through the implementation of a common foreign and security policy" (Art. 2), but "the Member States shall support the Union's external and security policy actively and unreservedly in a spirit of mutual solidarity" (Art. 11,2). One way of making sense of this complex development is not to focus on an emerging constitution on the EU level, but instead to take the complex relationship with the member states as well as the unity of national and supranational legal orders into account and to try and see a constitution made up of the constitutions of the member states bound together by a complementary constitutional body consisting of the European Treaties. ${ }^{16}$ This Verfassungsverband as he calls it - was labelled by Pernice as a multi-level constitution: ${ }^{17}$

'This perspective views the Member States' constitutions and the treaties constituting the European Union, despite their formal distinction, as a unity in substance and as a coherent institutional system, within which

11 See D.M. Curtin and I.F. Dekker, 'The Constitutional Structure of the European Union: Some Reflections of Vertical Unity-in-Diversity', in: N. Walker et al. (eds.), Convergence and Divergence in European Public Law, Oxford, 2002, pp. 59-78.

12 T. Eijsbouts, 'Constitutional Sedimentation', Legal Issues of European Integration, 1996, no. 1, pp 51-60.

13 The concept is used here in the definition used in institutional legal theory (ILT) as: "distinct legal systems governing specific forms of social conduct within the overall legal system". See D.W.P. Ruiter, Legal Institutions, Dordrecht: Kluwer Academic Publishers, 2001, at 71.

14 Cf. Fassbender (1998), op. cit., at 566-567: "In principle, there cannot be a community, understood as a distinct legal entity, in the absence of a constitution providing for its own organs. Legal personality requires the actual ability to perform legal acts."

15 This is not to say that this phenomenon is not more general. In the words of Joerges: "De facto, the dependence of European governance on the collaboration of the Member States is drastically perceptible everywhere one looks. This dependence determines the EU's shaping of political programmes which are then transposed with the help of the committee system; the inclusion of non-governmental organisations, and the preference for 'soft law' and information policy measures. Equally important is the fact that the freedoms that European law guarantees are exercised outwith, or away from' one's own member State and, at the same time, can be upheld against one's own 'sovereign'." Joerges (2002), op. cit, at 33. The same line of thought can be discovered in A. Milward, The European Rescue of the Nation State, London: Routledge, 1992.

16 Cf. Lenaerts and Desomer, op. cit., at p. 1219: "[t]here are no convincing legal arguments why a Constitution may not be made up of a variety of interconnected Treaty texts founding the legal order".

17 Pernice (1999), op. cit., at 706-707 and 715. The notion finds its source in the multi-level governance literature, popular in some political science approaches. See for instance L. Hooghe and G. Marks, Multilevel Governance and European Integration, Lanham, MD, etc.: Rownan \& Little field Publishers, 2001. In legal studies the notion was picked up and applied by N. Bernard, Multilevel Governance in the European Union, The Hague, etc.: Kluwer Law International, 2002. 
competence for action, public authority or, as one may also say, the power to exercise sovereign rights is divided among two or more levels. [...] This concept treats European integration as a dynamic process of constitutionmaking instead of a sequence of international treaties which establish and develop an organization of international cooperation. The question 'Does Europe need a Constitution' is not relevant, because Europe already has a 'multilevel constitution' [...]. According to the concept of 'multilevel constitutionalism', the Treaties are the constitution of the Community - or, together with the national constitutions, the constitution of the European Union - made by the peoples of the member States through their treaty-making institutions and procedures".

This approach acknowledges that one cannot simply place the different issue areas of the Union (such as the 'internal market', or 'foreign policy') under either the heading of supranationalism of intergovernmentalism, but that competences related to these issue areas are allocated between the different levels of decision-making. ${ }^{18}$ In order to place this argument in a more general setting, I will first investigate the emergence of a 'multi-level constitution' in the area of European foreign affairs (section 2). This is followed by an analysis of the current constitutional relationship between the Union and its member states in the area of foreign and security issues (section 3). Section 4 will subsequently analyse 'flexibility' as a development that may have an effect on the constitutionalisation of the external relations of the EU. Finally, section 5 will be used to make some concluding observations.

The notion of a constitution was explicitly used by the European Convention on the future of Europe, which presented a new Draft Treaty establishing a Constitution for Europe on 20 June 2003. It is believed that, even when this draft will be adopted by the subsequent Intergovernmental Conference, is does not fundamentally alter the position of CFSP in the European Union. Despite the disappearance of the distinct pillars of the Union - as proposed by the European Convention - CFSP will retain a special position in the new framework and its procedures will still be different from those in other areas. Moreover, CFSP is not even mentioned as one of the 'areas of shared competence' in Article $\mathrm{I}-13$ of the draft, but is described, in similar wordings as used in the current Treaty, in separate sections (I-15, I-39 and I-40).

\section{The Emergence of a Multi-Level Constitution}

\section{A. European External Relations:The 'Personification’ of a Treaty-Relationship}

At one moment in time the external identities of the current member states of the European Union started to coincide partly with the external identity of, what we now call, the European Union. This moment may have been the entry into force of the Treaty on European Union, but there are also good reasons to locate this moment earlier in time, for instance with the entry into force of the Single European Act in 1987 or even earlier during the European Political Cooperation that largely took place on the basis of custom and subsequent codification. ${ }^{19}$ The political cooperation that took place between the members of the European Economic Community during the 1970s and 80s could not be regarded a formal treaty relationship. Nevertheless, (codified) custom surely reflected a contractual legal relation between the participating states. ${ }^{20}$ The procedural agreements laid down in Declarations, and later on in the Single European Act reflected the emergence of a constitution which increasingly

18 See on this issue U. Di Fabio, 'Some Remarks on the Allocation of Competences between the European Union and its Member States', CML Rev., 2002, pp. 1289-1301.

19 The debate, of course, started earlier. See R.T. Griffiths interesting analysis Europe's First Constitution: The European Political Community, 1952-1954, London: Federal Trust, 2002. It always remains interesting to note that the originally envisaged "supranational European Community" was explicitly regarded to have legal personality (art. 4 of the Statute of the European Community, 1953), and had a clear 'foreign policy' dimension.

20 See more extensively: R.A. Wessel, The European Union's Foreign and Security Policy: A Legal Institutional Perspective, The Hague: Kluwer Law International, 1999, Chapter 1. 
posed procedural restraints on the participating states. ${ }^{21}$ Indeed, participating states; they only became member states after the entry into force of the EU Treaty.

From that moment on there could no longer be any doubt about the fact that there exists a legal system in distinction from the legal systems of the member states in he area of foreign affairs. The possibility of viewing the European Union as a legal person was the result of - what Ruiter calls a 'legal operation of personification'. ${ }^{22}$ Where 'natural personality' is a feature of human entities, personification is not only possible of non-human entities, but even of 'incorporeal' things, that is 'mental constructs', like 'states' or 'international organisations'. Modern law systems allow wills to be imputed to these incorporeal things through a legal act of personification.

In order to be able to understand what exactly happens when we allow an international organisation like the European Union to act externally, that is vis-à-vis third parties, it is helpful to see how this modification from 'contractual relationship' to 'association' takes place. Ruiter defines an association as "a personified multilateral contractual legal relation". ${ }^{23}$ But, how is a contractual legal relation turned into an association that is capable of entering into legal relationships with third parties? After all, contractual relations only regard parties to the contract, which implies that no party can enter into transactions with third parties on behalf of the others. Ruiter claims that, what we do is in fact 'personify' the contractual relation by making three adjustments: ${ }^{24}$

"1. Contractual consensus is abandoned in favour of collective choice processes whose outcomes are no longer conceived of as resulting from concordant expressions of the individual wills of all participants.

2. The abandonment of the idea of decisions as founded on contractual consensus is accompanied by the construction of a generalised will imputed to the legal institution itself: the association. By imputing a will to it, the association is accorded legal personality. The fundamental legal relation between the newly created legal person and the parties to the original contract are the rights of the latter to participate in the collective choice processes.

3. An association with legal personality is treated on a par with natural persons (capacity for rights), is capable of performing legal acts (legal capacity), and is responsible for behaviour flowing from the will imputed to it (legal liability)."

This means that:

"The original multilateral legal relation between parties to the contract is thus transformed into a bundle of bilateral relations between the association and its members. By virtue of these relations the association can deal with third persons according to the aggregate will of its members".

Thus the external possibilities and competences of an association are closely linked to its internal legal structure. The complex (constitutional) relationship that forms the subject of this paper only announces itself when indeed the external relations of the member states are complementary to and at the same time governed by the body of procedural rules through which the external behaviour of the association is formed. The current Treaty on European Union reflects this situation, in which relations with third states and organisations are simultaneously defined at the national and the European levels, by

21 In this respect it is interesting to take a renewed look at Weiler's remarks made in 1985 regarding the European Political Cooperation: "Even if federations have a unitary external posture [which the EPC lacks according to Weiler - RAW], it is arguable that the federal principle may vindicate itself in the internal process of foreign policy-making". This leads Weiler to conceive of EPC in 1985 already as "a new experiment of a non-unitary foreign policy process and foreign posture which may veritably be called the federal option [as an organisational principle] of foreign affairs". J.H.H. Weiler, "The Evolution of Mechanisms and Institutions for a European Foreign Policy: Reflections on the Interaction of Law and Politics', EUI Working Paper No. $85 / 202,1985$, at 3.

22 D.W.P. Ruiter, 'Forms of Legal Institutions', internal paper University of Twente, February 2002.

23 lbid., at 5.

24 Ibid., at 5-6. 
international legal persons (the member states and the Union) that are separate, but at the same time inseparable. $^{25}$

\section{B. A Division of External Competences?}

Departing from the notion of a unity of the constitutional regulation of the external relations of the Union and its member states, the question comes up how the competences in this field are divided among the two distinct levels. Indications can first of all be found in the Preamble and the objectives of the Treaty on European Union. In the Preamble, the Heads of State declare they are:

"Resolved to implement a common foreign and security policy including the eventual framing of a common defence policy, which might lead to a common defence, thereby reinforcing the European identity and its independence in order to promote peace, security and progress in Europe and in the world".

The beginning of the quoted statement may convey the impression that since the Heads of State, when establishing the EU, were 'resolved to implement a common foreign and security policy', it should be regarded as an overall objective and not as something that was created by the Treaty. Does this mean that the establishment of a Common Foreign and Security Policy (CFSP) is merely an objective of the Union and that it does not yet exist? No, any possible confusion as to the status of CFSP was already eliminated by the original Article $\mathrm{J}$ of the $1992 \mathrm{TEU}$, which left no doubt as to the fact that a CFSP is not an end in itself, since that Article unconditionally stipulated that "[a] common foreign and security policy is [hereby] established". ${ }^{26}$ Hence, in the above quoted provision the emphasis should be on the "implementation" of a CFSP. This is underlined by Article 11 in the 1997 TEU, which provides that "[t]he Union shall define and implement a common foreign and security policy [...]" ${ }^{27}$ Thus, since 1993 there exists a Union foreign and security policy - at least in a formal institutional sense.

The purposes mentioned in the Preamble come close to the ones the Heads of State had formulated in the Preamble to the Single European Act (SEA, 1986) in which they stated that they were "aware of the responsibility incumbent upon Europe to aim at speaking increasingly with one voice and to act with consistency and solidarity in order more effectively to protect its common interests and independence [...] so that together they may make their own contribution to the preservation of international peace and security [...]". The inconsistencies in this statement were, however, even more striking. By "together" making their "own contribution" the states aimed to "speak with one voice" and to "act with consistency and solidarity". The words chosen explain the absence of a reference to a common policy; the purpose of the SEA was, as its Article 30 stipulates, to establish a "European Cooperation in the sphere of foreign policy". The Union Treaty aims to go beyond this in establishing a common policy, and not just an ad hoc adaptation of different individual policies.

The purpose set forth by the Heads of State in the Preamble of the TEU reflects their decision to implement a common foreign and security policy. But, who is responsible? While the Preamble prima facie hints at the states themselves as being responsible, Article 2 of the Common Provisions of the TEU repeats this purpose as an "objective of the Union". Obviously, there is a difference between the 'states', as represented by the Heads of State as the original 'contractors', and the 'European Union' they created. According to Article 1 TEU the European Union is established among the High Contracting Parties. The concept of 'Union' is not explicitly defined by the Treaty; it is said to be

25 See on the individual international legal personality of the Union my 'The International Legal Status of the European Union', EFA Rev., 1997, pp. 109-129; and 'Revisiting the International Legal Status of the EU', EFA Rev., 2000, pp. 507-537.

26 The fact that a CFSP is established, and not the CFSP, for some authors was a reason to conclude on the non-exclusive character of CFSP; CFSP has not replaced all aspects of the foreign and security policies of the member states, it only exists in the areas in which the member states come to an agreement. See V. Constantinesco, R. Kovar \& D. Simon, Traité sur l'Union Européenne: Commentaire article par article, 1995, at 786 .

27 The former Article J, by which CFSP was established, was deleted by the Amsterdam Treaty. 
"founded on the European Communities, supplemented by the policies and forms of cooperation established by this Treaty". Regardless of its precise definition, it follows from these descriptions that the 'Union' is not to be equated with the 'states' ("High Contracting Parties") by which it was established. ${ }^{28}$ The objective of the Union, as stipulated in Article 2 TEU, is:

"to assert its identity on the international scene, in particular through the implementation of a common foreign and security policy including the progressive framing of a common defence policy, which might in time lead to a common defence $[\ldots] "$.

This objective is, however, slightly different from the objective of the states when they created the Union. ${ }^{29}$ For the purpose of the present paper, the question is who is responsible for attaining objectives that are partially overlapping but not entirely phrased in identical words.

The original 1992 Article J.1 provided some insight into this issue by stipulating that "the Union and its Member States shall define and implement a common foreign and security policy". This provision confirmed the view that both the Union and the states are responsible for the implementation of a CFSP. It did not define, however, the difference between the Union and the states. It even complicated their relationship by referring to "Member States". ${ }^{30}$ Regarding the European Political Cooperation (EPC), the SEA consequently spoke of "High Contracting Parties", since the EPC was not part of the European Community and it was not considered possible to be a 'member' of the EPC. Regardless of the fact that the Union is not presented as an international organisation anywhere in the TEU, the introduction of the term 'Member States' - which is still used throughout the entire text underlines the fact that a new entity was created, an new international legal entity of which it is possible to become a 'member'.

While careless use of terminology may of course very well be the explanation, an affirmative answer to this question seems to be supported by Article 11. This Article sheds light on the division of competences as it refers to the Union as the only responsible actor for the definition and implementation of CFSP. According to the second paragraph of that Article, the member states are to "support" the Union in that respect. Several other provisions underline the status of the Union, not only as a separate actor, but even as they key actor in CFSP. Thus, the Union shall pursue objectives (Article 12), the Union has a (external and security) policy (Article 11, paragraph 1 and Article 17, paragraph 1), ${ }^{31}$ the Union may avail itself of another organisation (Article 17, paragraph 3 ), the Union can have a position (Article 18, paragraph 2), and the Union can take action (Article 13, paragraph 3).

Most important, however, is that CFSP decisions (regardless of their form and substance) are not merely agreed on by the EU member states, but that they are adopted by an organ: the Council of the European Union. The pivotal position of the Council in CFSP decision-making, as well as in decisions on national deviations from agreed policy is obvious. ${ }^{32}$ Decision-making by the Council rests on explicit power-conferring norms. Earlier studies revealed that it would be difficult to hold the view

28 This seems to be confirmed by Article 6, paragraph 3, which provides that "[t]he Union shall respect the national identities of its Member States".

29 Instead of the 'reinforcement of the European identity and independence', and through that the 'promotion of peace, security and progress in Europe and the world', the objective of the Union is to "assert its identity on the international scene", for which the implementation of a CFSP is to be regarded as the means. The different terms used - 'reinforce' and 'assert'; 'in Europe and the world' and 'on the international scene' - are not necessarily contradictory (regardless of the question why 'Europe' does not belong to 'the world').

$30 \quad$ Cf. also in this respect Article 6, paragraph 3.

31 Article 30 , paragraph 5 of the Single European Act only referred to "policies agreed" within the cooperation framework of the EPC.

32 See Wessel (1999), op. cit., Chapter 4 and 5. In this respect also Chr. Trüe, Verleihung von Rechtspersönlichkeit an die Europäische Union und Verschmelzung zu einer einzigen Organisation deklaratorisch oder konstitutiv?, Universität des Saarlandes: Vorträge, Reden und Berichte aus dem EuropaInstitut, No. 357, 1997 at 22, who pointed to the different terms used in the EPC period (when the participating states 'acted in common') and the CFSP cooperation (which leads to 'joint actions'). However, the term 'joint action' in fact does not make sense when it is seen as a decision of the Council. The best way out in this respect is to regard 'joint actions' as decisions of the Council, in which this organ decides that the member states of the Union have to act jointly. 
that the Council is merely a meeting hall for fifteen states. ${ }^{33}$ Without repeating the arguments, it is clear that the Council can be seen as an institution of the European Union, which finds its direct basis as well as its competences in the TEU.

This brings about the question of how the national legal orders of the member states are related to the EU legal order in this area. Is the latter to be conceived as a 'supranational' order which by definition sets aside any conflicting national legal norm? Does the notion of a single, albeit 'multilevel', constitution exclude the possibility of looking at the different legal orders as operating in a 'dualist' fashion? And, if this is the case, do the norms created at the European level affect the citizens and other private parties within the national legal orders?

\section{The Constitutional Relationship between the Union and its Member States in Foreign Policy}

\section{A. The Validity Relation between the Two Levels}

The acceptance of the idea of a multi-level constitution brings about two distinct questions concerning the hierarchy between the legal orders that can be found at the two levels. The first question concerns the validity relationship between different legal orders; the second question deals with the supremacy of rules in one order over rules in another. Applied to the topic of the present paper these questions can be phrased as follows: Is the validity of norms issued by international organisations derived from another legal order, and if so what consequences does this have for the supremacy of norms of other legal orders over these norms or vice versa in case of a conflict between these norms? This question becomes relevant in particular in relation to the (direct) effect of decisions of international organisations in the legal orders of the member states and thus to the way in which both the Union and its member states (jointly or individually) may approach the 'outside world' (section 3.C).

Regarding the first question, Kelsen pointed to the existence of different 'basic norms' as the ultimate 'source' of distinct legal orders, but he also argued that the source of two distinct legal orders can be the same when one order is based on the other. ${ }^{34}$ Kelsen argued that there are four conceivable (validity) relations between two distinct orders (or 'norm systems') $:^{35} 1$ both systems are completely divided ("unabhängig") - that is: they have distinct sources of validity; 2 norm system A derives its validity from norm system B; 3 norm system B derives its validity from norm system A ("überund unterordnung"); and 4 both orders are of equal value, they are (relatively) independent subsystems, coordinated by an overarching superior order ("Koordination"). The above analyses on the personification of a contractual legal relationship shows that the validity of a treaty-based legal order is derived from the valid competence of states to establish these international orders. This, however, is not enough. States can only do this on the basis of a 'third' norm, that is not part of their own legal order. A national legal system as such cannot be a sufficient legal basis for the establishment of a valid international agreement between sovereign states. There has to be an external rule according to which the expressed will by a sovereign state counts as a valid way to be bound by an international agreement. $^{36}$

33 See for references Wessel (1999), op. cit., at 74-76.

$\mathrm{H}$. Kelsen, Das Problem der Souveränität und die Theorie des Völkerrechts: Beitrage zu einer reinen Rechtslehre, Scientia Aalen, 1928/1960 at 105: "In der Einheit und Besonderheit dieses Ursprungs, dieser Grundnorm, liegt das principium individuatis, liegt die Besonderheit einer Ordning als eines Systems von Normen". Despite its age, this book still serves as one of the clearest interpretations of the concept of sovereignty and the relation between the international legal order and national legal orders (or 'states' in Kelsen's line of reasoning).

35 Ibidem, at 104. Cf. also W. Werner, Het recht geworden woord: over de geschiedenis van het rechtspositivisme en de mogelijke betekenis van het pramgmatisme voor de toekomst daarvan, Enschede: Universiteit Twente, 1995 at 158.

36 See also Curtin and Dekker (2002), op. cit. 
At the same time this relationship points to the unity of the international legal system. States are only connected to each other because they form part of an overarching international (or better in this respect: 'supranational') legal order. Returning to Verdross: ${ }^{37}$

"Von einer einheitlichen Völkerrechtsordnung kann nur die Rede sein, wenn sämtliche Völkerrechtsnormen einen Verweisungszusammenhang, einen Delegationszusammenhang von berufenden und berufenen, von delegierenden und delegierten Normen bilden. Dazu ist vor allem erforderlich, daß eine oberste Norm oder ein oberstes Normengefüge, kurz eine Grundnorm in Geltung steht, auf die der geltungsgrund aller übrigen Völkerrechtsnormen unmittelbar oder mittelbar zurückgeführt werden kann. Bloß der bestand einer solchen Grundnorm, die die normative Grundlage für alle übrigen Völkerrechtssätze liefert, vermag die Einheitlichkeit des Völkerrechtes zu verbürgen, da die Einheitlichkeit jedes Normensystems nur dadurch möglich ist, daß alle seine Normen aus einem einheitlichen Brennpunkte ausstrahlen, über den unde durch den sie zusammenhängen. Das Problem der Einheitlichkeit des Völkerrechtes steht und fällt daher mit dem Probleme der völkerrechtlichen Grundnorm."

However, whenever associations of states (multilateral treaties) have been transformed - through a legal act of personification - into new legal entities, these international organisations would also form part of the supranational legal order. States can only create these new legal entities because a supranational legal order allows them - or makes possible - to do this. The acceptance of the existence of an overarching legal order, consisting of legal sub-systems (states and international organisations) depends on the acceptance of the unity of this legal system, in the sense that the Grundnorm of this system is at the same time the source of the norms in the subsystems. This consequence of this assumption is that once a norm is validly created anywhere in the international legal order, this validity cannot be denied in any of the suborders. This, in turn, causes problems for advocates of the classic dualist approach, which claims that the legal systems of international organisations and the member states are completely independent, separate from each other and from the overarching legal order, in the sense that they have different legal sources and different legal subjects. ${ }^{38}$ In this approach the legal system of the international organisation provides rules for the member states (and for the functioning of the organisation itself), whereas the legal system of the member states regulates the activities of its citizens and other private persons (and the functioning of the state itself). In other words, legally valid rights and duties of individuals can only be created under the national legal system of the member states. Apart from logical problems, ${ }^{39}$ simple empirical tests reveal the impossibility of upholding this notion. Many rules of positive international law purport to bind private persons directly, without interference from national law. Under general international law, obvious examples of such rules relate to the international criminal responsibility of individuals for international crimes. Other examples may be found in the legal system of the European Union providing a range of treaty-based rules, regulations and decisions directly creating rights and duties for individuals and other legal persons. As shown by the European Community - and increasingly by other parts of the Union - the legal order of the member states cannot claim to be immune to norms created in another legal subsystem of the international legal order. ${ }^{40}$

37 Verdross (1926), op. cit., at 12.

38 See also I. Weyland, 'The Application of Kelsen's Theory of the Legal System to European Community Law - The Supremacy Puzzle Resolved', in Law and Philosophy, 2002, 1-37. Although dealing with Community Law, Weyland argues: "[...] and analysis based on Kelsen's theory must reject a dualist conception and will lead to the assumption of only one basic norm of a unified set of norms, where the basic norm, either of the Community or of each Member State, validates both Community and national constitutional norms. The principle of the supremacy of Community over national constitutional norms may be fitted into either model". Weyland thus does not see a basic norms in an 'overarching' legal order, but rather in either the national legal order or the legal order of the international organisation.

39 At least when one accepts Kelsen's ideas on the unity of a legal system with the basic norm as a common source of validity for norms of both states and international organisations, and the idea that state sovereignty can only be uphold on the basis of the notion that all states form part of one legal system which also provides the norm to respect the territorial sphere of validity of other states. Ibidem, at 28.

40 Curtin and Dekker (2002), op. cit. 
In conclusion, both states and international organisations seem to be sub-systems of the overall supranational legal order, the existence of which is, is turn, determined by the fact that states and international organisations exist. Thus, this supranational order not only defines the existence of states, but also coordinates and makes possible the relations between these states. ${ }^{41}$ The fact that states are allowed to conclude treaties and to create international organisations, and that they are bound by these agreements, implies the existence of a 'higher' legal order with the pacta sunt servanda-norm as its most obvious Grundnorm. ${ }^{42}$

\section{B. Consistency and Delimitation between the Constitutional Levels}

The starting point of the unity of the legal order in terms of the validity of the norms in that order was to present the regulation of European foreign relations as a single (multi-level) constitution in which norms at one level cannot be isolated from norms at the other. This unity of the legal system can also be found in H.L.A. Hart's theory of law, in which the unity derives from the rules of conflict within the rule of recognition, which determine relations of supra- and subordination between rules deriving from different sources. ${ }^{43}$ One consequence of this idea is that the external relations that are based on this constitution are consistent, in the sense that third parties are not confronted with a conflicting legal output. At the same time the constitution may provide for a delimitation of the competences of the actors on the different levels. ${ }^{44}$ The notions of delimitation and consistency are in particular reflected in four principles underlying the cooperation between the member states and the EU, which may therefore be considered key constitutional principles in this area: the information and consultation obligation, the loyalty obligation, subsidiarity, and the procedures on external representation.

\section{The Information and Consultation Principle}

The autonomous competences of the Union in relations with third parties imply the existence of procedural restrains on the member states, aiming at a consistent external policy, but at the same time fixing a vertical division of competences. The key provision in this respect is to be found in the socalled information and consultation obligation. This obligation forms part of the concept of systematic cooperation and in fact builds on the system of European Political Cooperation (EPC), in which it was agreed that the participating states "undertake to inform and consult each other on any foreign policy matters of general interest". ${ }^{45}$ It is this systematic cooperation that in fact formed the core of EPC from 1970-1993. And in CFSP it still serves as the key notion, in the absence of which it would be impossible for the Union to define and implement a foreign and security policy. In that respect it could be seen as a necessary pre-legislative procedure. The systematic cooperation referred to in the list of CFSP means in Article 12 TEU is to be established in accordance with Article 16, which contains the actual procedural obligations. ${ }^{46}$ In principle, the scope of issues to which the systematic cooperation

41 Cf. Kelsen (1928), op. cit., at 204-5: “daß über den Staaten angesehenen Gemeinwesen eine Rechtsordnung steht, die die Geltungsbereiche der Einzelstaaten gegenseitig abgrenzt, indem sie Eingriffe des einen in die Sphäre des andern verhindert oder doch an gewisse, für alle gleiche Bedingungen knüpft; eine Rechtsordnung die das gegenseitige Verhalten dieser Gemeinwesen durch für alle gleiche Normen regelt, bei der einzelnen Staaten grundsätzlich jeden Rechtsmehrwert des einen gegenüber dem anderen ausschließt, und die, als eine Universalordnung, die zu besondern Rechtssubjecten personifizierten einzelstaatlichen Rechtsordningen aus ihrer isoliertheit (und damit aus ihrer Höchstwertigkeit oder Souveränität) heraushebt, um sie - nunmehr als Teilordnungen - zu einen Ganzen, zu einer 'Gemeinschaft' zu verbinden".

42 Verdross (1926), op. cit., at 32.

43 See also Weyland (2002) op. cit., at 33. According to Weyland this is why it is arguable that Hart's theory also supports the monistic model.

44 The same problems occur in a 'horizontal' dimension within the European Union. See R.A. Wessel, 'The Inside Looking Out: Consistency and Delimitation in EU External Relations', CML Rev., 2000, pp. 11351171.

45 See Article 30, paragraph 2(a) of the Single European Act (1986).

46 The contents of Article 16 (J.2, paragraph 2) were not modified throughout the negotiations of the TEU and already formed part of the Luxembourg Draft of 18 June 1991 (Article G of the CFSP provisions). 
applies is not subject to any limitation regarding time or space: "Member States shall inform and consult one another within the Council on any matter of foreign and security policy [...]". Nevertheless, Article 16 immediately fills this lacuna in adding the words "of general interest". The European Council has not provided any further specification of 'general interest' in Article 16. This seriously limits the information and consultation obligation in the first part of this Article: on the one hand, member states are obligated to inform and consult one another, whereas on the other hand they are given the individual discretion to decide whether or not a matter is of 'general interest'. This underlines the important procedural role of the 'national level' in the arrangement.

Nevertheless, it can be asserted that the member states are indeed obligated to inform and consult one another. Through the information and consultation obligation the member states ordered themselves to use it as one of the means to attain the CFSP objectives in Article 11. Taking into account the nature of the information and consultation obligation, it is rather unfortunate that the Treaty does not further define the obligation. In order to establish the content of the obligation it is therefore necessary to turn to general descriptions of the consultation obligation in international law. A general definition was for instance formulated by Möstl, who defined the consultation obligation in international law as:

"Die von Staaten oder anderen Völkerrechtssubjekten durch völkerrechtlichen Vertrag vereinbarte Verplichtung zu einer auf der Grundlage der Gleichheit und Gegenseitigkeit ruhenden und von einer Gemeinsamkeit der Interessen getragenen Beratung zwischen einer den Organen der Vertragspartner mit dem Ziel der Herbeiführung einer den Interessen der Beteiligten gemäßen gemeinsamen Haltung in einer bestimmten Situation". ${ }^{47}$

A more material obligation could be phrased as "das Gebot, von der endgültigen Festlegung einer eigenen Position Abstand zu nehmen, solange nicht die Anhörung des Konsultationspartners stattgefunden hat". ${ }^{48}$ There are no reasons to assume that the notion of consultation as used in Article 16 deviates from these general definitions, which leads us to conclude that the EU member states are to refrain from making national positions on CFSP issues of general interest public before they have discussed these positions in the framework of the CFSP cooperation.

With regard to the obligation itself, it seems that the mandatory way in which the provision is phrased somewhat departs from the more 'intention-oriented' approach in the Single European Act (SEA). Article 30 of the SEA stipulated that "[t]he High Contracting Parties undertake to inform and consult each other [...]" ${ }^{49}$ The chosen words may indeed call for a distinction. While 'undertake' seems to go beyond 'intend', is does not seem to be the same as 'shall'.

Informing and consulting one another should take place 'within the Council'. Keeping in mind the requirement of systematic cooperation, this should not be interpreted as 'only within the Council'. Cooperation within the preparatory organs (Political Committee, COREPER, and working groups), as well as bilateral and multilateral consultations are equally covered by this obligation. In fact, it is in these bodies that the actual systematic cooperation takes place. A second reason not to restrict the cooperation to meetings of the member states in the Council, may be found in Article 19. According to this provision, member states shall coordinate their action in international organisations and at international conferences as well. Even when not all member states are represented in an international organisation or an international conference, the ones that do participate are to keep the absent states informed of any matter of common interest (infra section 3.B.4).

\section{The Loyalty Principle}

These observations are supported by Article 11, paragraph 2, which reflects a more general 'loyalty obligation': "The Member States shall support the Union's external and security policy actively and

\footnotetext{
$47 \quad$ W. Möstl, Die Konsultationsverpflichtung im Völkerrecht, Diss.jur., Würzburg, 1967 at 68.

48 Th. Jürgens, Die gemeinsame Europäische Aussen- und Sicherheitspolitik, Köln: Carl Heymanns Verlag, 1994 at 210.

49 Emphasis added.
} 
unreservedly in a spirit of loyalty and mutual solidarity" ${ }^{50}$ This obligation is not further defined. A possible interpretation could be found in one of the other Union areas, where one finds a comparable provision in Article $10 \mathrm{EC} .^{51}$ Like Article $10 \mathrm{EC}$, the CFSP provision contains a positive obligation for the member states to develop actively the Union's policy in the indicated area, which since the Amsterdam Treaty even includes the obligation to "work together to enhance and develop their mutual political solidarity". Moreover, the negative obligation not to undertake "any action which is contrary to the interests of the Union or likely to impair its effectiveness as a cohesive force in international relations" is also comparable to Article $10 \mathrm{EC} .^{52}$

A comparison of the CFSP loyalty obligation with Article $10 \mathrm{EC}$ reveals its potential impact. The latter Article has proven its added value in Community law; it is often seen as the basis of the constitutional nature of Community law ${ }^{53}$ and it has been frequently used by the Court of Justice in its case law, albeit that the materialisation of the obligation needs to be established in conjunction with other provisions in the Treaty or in secondary law. ${ }^{54}$ Article $10 \mathrm{EC}$ has thus been interpreted so as to include: 1 the obligation to take all appropriate measures necessary for the effective application of Community law; 2 the obligation to ensure the protection of rights resulting from primary and secondary Community law; 3 the obligation to act in such a way as to achieve the objectives of the Treaty, in particular when Community actions fail to appear; 4 the obligation not to take measures which could harm the effet utile of Community law; 5 the obligation not to take measures which could hamper the internal functioning of the institutions; and 6 the obligation not to undertake actions which could hamper the development of the integration process of the Community. ${ }^{55}$ Hence, far-reaching obligations, which when applied to CFSP could seriously limit the freedom of the member states.

While it cannot be denied that the wording of the CFSP provision provides no reasons to limit its scope in relation to Article $10 \mathrm{EC}$, the absence of any competences of the Court of Justice within CFSP makes the question whether these interpretations could also apply to Article 11, paragraph 2 a very abstract and theoretical one. On the other hand, even when the member states cooperate outside the explicit treaty provisions, Article 10 assures their solidarity. In fact, the Court has made this abundantly clear when it established that the obligations on the basis of Article $10 \mathrm{EC}$ may extend beyond the limits of Community law:

"Article 5 [the former Article 10; RAW] of the treaty provides that the Member States must take all appropriate measures, whether general or particular, to ensure fulfilment of the obligations arising out of the treaty. If, therefore, the application of a provision of community law is liable to be impeded by a measure adopted pursuant to the implementation of a bilateral agreement, even where the agreement falls outside the field of application of the treaty, every member state is under a duty to facilitate the application of the provision and, to that end, to assist every other member state which is under an obligation under community law". ${ }^{56}$

50 One could be struck by the word 'external', which in this provision replaces the familiar term 'foreign', but there are no reasons to give any specific meaning to this inconsistency.

51 Article 10 EC: "Member States shall take all appropriate measures, whether general or particular, to ensure fulfilment of the obligations arising out of this Treaty or resulting from action taken by the institutions of the Community. They shall facilitate the achievement of the Community's tasks. They shall abstain from any measure which could jeopardise the attainment of the objectives of this Treaty".

52 According to F. Fink-Hooijer, 'The Common Foreign and Security Policy of the European Union', EJIL, 1994, 173-198 at 180, Article 11, paragraph $2(\mathrm{~J} .1,4)$ should not be read as to include the establishment of a CFSP: "From a strictly legal point of view, the restrictive loyalty clause can only apply and have effect once a European Union interest or policy has been defined".

53 See for instance J. Temple Lang, 'Community Constitutional Law: Article 5 EEC Treaty', CMLRev., 1988, 595 at 221; and K.J.M. Mortelmans, 'The Principle of Loyalty to the Community (Article 5 EC) and the Obligations of the Community Institutions', Maastricht Journal of European and Comparative Law, 1998, 67-88.

54 E.g. Case 78/70, Deutsche Grammophon.

55 See in particular O. Due, 'Artikel 5 van het EEG-Verdrag, een bepaling met een federaal karakter?', SEW, 1992, 355-366 at 355-366; and J.E. De Cockborne et al., (1992) Commentaire Mégret, Vol. 1, Brussel, 1992 at $26-42$.

56 Case 235/87, Annunziata Matteucci v. Communauté Française de Belgique, para. 19. Cf. also H.G. Krenzler and H.C. Schneider, 'Die Gemeinsame Außen- und Sicherheitspolitik der Europäischen Union - Zur Frage der Kohärenz', EuR, Heft 2, 1997, 144-161 at 147 with regard to 'mixed actions': "[l]t is doubtful whether the CFSP consistency obligation can still be seen as binding only under international law. When CFSP joint actions are combined with Community measures in an operation by the Union as a whole, the Community 
The reference to cooperation outside the field of application of the EC Treaty seems to imply that the scope of Article 10 EC reaches across the Union's three main areas. This is in particular apparent when the principle of consistency is taken into account. According to Article 3 TEU, the Union shall in particular ensure the consistency of its external activities. It could be argued that irrespective of the separate CFSP loyalty obligation, a failure to comply with the consistency requirement could, at least in certain cases, be seen as a breach of Article 10 of the EC Treaty, constituting grounds for the justiciability of consistency. ${ }^{57}$ The loyalty principle thus seems to have evolved - in the words of Curtin and Dekker - "from a duty of cooperation on the part of the Member States to a multi-sided duty of loyalty and good faith in the vertical relationship between the Union and its Member States and also among the Member States themselves and among Union institutions themselves". ${ }^{58}$

\section{The Subsidiarity Principle}

The CFSP loyalty clause may come in conflict with another important Union principle: 'subsidiarity'. ${ }^{59}$ However, the necessary application of this principle to CFSP matters is not obvious. The principle of subsidiarity is defined in the EC Treaty (Article 5) and referred to Article 2 TEU: "The objectives of the Union shall be achieved [...] while respecting the principle of subsidiarity as defined in Article 5 of the Treaty establishing the European Community" ${ }^{60}$ According to the central part of Article $5 \mathrm{EC}$, the principle of subsidiarity entails that:

"In areas which do not fall within the exclusive competence, the Community shall take action, in accordance with the principle of subsidiarity, only if and in so far as the objectives of the proposed action cannot be sufficiently achieved by the Member States and can therefore, by reason of the scale or effects of the proposed action, be better achieved by the Community".

On the basis of the wording of Article 2 TEU and Article 5 EC, one could argue that the subsidiarity principle does not extend to any other area of the Union but the European Community. Article 2 stipulates that the objectives of the Union shall be achieved while respecting the principle of subsidiarity as defined in Article $5 \mathrm{EC}$. Article $5 \mathrm{EC}$, in turn, defines subsidiarity as the principle that the Community shall only act if the objectives of the proposed action cannot be achieved by the member states. Hence, if the Community abides by this principle, the Union's obligation in Article 2 TEU is fulfilled. Some support for this view can be found in the analysis of the subsidiarity principle presented by the European Council of Edinburgh in December 1992 or in the fact that the Protocol on the Application of the Principles of Subsidiarity and Proportionality was annexed to the EC Treaty only and not to the TEU. ${ }^{61}$ Despite a few general references to a Union-wide application of subsidiarity ("[The] European Union rests on the principle of subsidiarity" and "the principle of subsidiarity as a basic principle of the European Union"), the concrete analysis of the European Council is restricted to the application of subsidiarity by the Community. It even observes that "The Treaty on European Union obliges all institutions to consider, when examining a Community measure, whether the provisions of

obligation imposed by Article 5 of the EC Treaty [now Article 10; RAW] spreads into the domain of CFSP, meaning that consistency could be considered obligatory under Community law as well as international law. [...] A failure to comply with the consistency requirement could, at least in certain cases of joint action, be seen as a breach of Article 5 of the EC Treaty, constituting grounds for the justiciability of consistency".

57 Ibidem, at147.

58 Curtin and Dekker (2002), op. cit., at 12. See also A. Verhoeven, The European Union in Search of a Democratic and Constitutional Theory, University of Leuven, 2001 (not yet published).

59 See in general on the principle of subsidiarity in the TEU...

60 L. Münch, 'Die Gemeinsame Außen- und Sicherheitspolitik (GASP): ein Schaf im Wolfspelz?', ZÖR, 389-417 at 395, for instance, argued "Bei der GASP kommt es damit zu einer entsprechenden Anwendung des Art. 3B EGV [now Art. 5; RAW]".

61 See European Council of Edinburgh, Presidency Conclusions, 11-12 December 1992, Annex 1 to Part A: Overall Approach to the Application by the Council of the Subsidiarity Principle and Article 3B of the Treaty on European Union [sic!], Bull. EC 12-1992. 
Article 3B [the original Article 5; RAW] are concerned". ${ }^{62}$ Hence, despite some confusing references to a possible Union-wide application of subsidiarity, the Treaty text, as well as an authoritative interpretation by the European Council, seem to hint at the non-applicability of the principle of subsidiarity as defined in Article $5 \mathrm{EC}$ to the non-Community areas of the European Union.

Nevertheless, the opposite view is more widely held. Subsidiarity is usually regarded as a Union-wide principle. Thus, according to some authors, any CFSP decision taken by the Council has to pass a test to determine whether action on the part of the European Union, as opposed to national action, can be justified. ${ }^{63}$ The main source of the Union-wide application of the subsidiarity principle is often found in the Preamble to the TEU, which explicitly refers to it and in Article 1 TEU stating that decisions are taken as closely as possible to the citizen. It remains difficult, however, to bring this requirement into line with the loyalty clause of Article 11, paragraph 2. After all, stressing that the parties to the TEU are first and foremost 'states', and only in the last resort 'member states' is obviously contradictory to the rule that they should actively develop the Union's policy and refrain from actions which are contrary to the interests of the Union or likely to impair its effectiveness. To be able to meet the requirements of a systematic cooperation, the subsidiarity test - when accepted - is to be taken in the course of the process of decision-making, and not prior to it. ${ }^{64}$ Any other representation of the subsidiarity principle in relation to CFSP would set aside the entire set of procedural obligations agreed upon. ${ }^{65}$ While one cannot be sure whether any CFSP decisions have failed because of an appeal to subsidiarity, practice has shown no references to the principle in the preamble of the CFSP decisions taken to date.

\section{External Representation}

From a legal point of view the world order is composed of unitary actors. Even in federations foreign relations are predominantly, if not exclusively, controlled by the central government. It is obvious that the Union cannot be seen as a (federal) state and that its member states have not given up their treaty-making competence.$^{66}$ On the other hand, the whole purpose of creating a CFSP (after twenty years of a rather intergovernmental EPC) was to enable the member states to speak with one voice by creating a new entity which would do this on their behalf. Again, however, the regulation of external representation is not solely to be found in the national constitutions or in the EU, but in a sophisticated and probably unprecedented constitutional regime in which external competences are allocated over two levels. Apart from the limited areas falling under the exclusive competence of the European Community, the member states retained their external competences. At the same time, however, the European Union itself was given autonomous external capacities. Apart from a large number of implied external capacities (ranging from the representation of the Union by the High Representative

62 See Part III of the Annex: 'Procedures and Practices'. Emphasis added. Cf. also A.G. Toth, 'A Legal Analysis of Subsidiarity', in: D . O'Keeffe and P. Twomey (Eds.), Legal Issues of the Maastricht Treaty, London: Wiley Chancery Law, 1994, 37-48 at 38: "[...] Article B [now Article 2; RAW] seems to make subsidiarity applicable across the whole Union Treaty. However, these provisions are more in the nature of political statements, declarations of intent, rather than provisions with precise legal effects".

63 See in particular Fink-Hooijer (1994), op. cit., at 178, and Münch (1997), op. cit., at 395. See also the Communication of the Commission to the Council and the European Parliament, 27 October 1992, Doc. SEC(92)1990 final.

64 The 1992 Treaty seemed to underline this when in this respect it referred to "areas in which the Member States have important interests in common" (Article J.1, paragraph 3); "whenever it [the Council] deems it necessary" (Article J.2, paragraph 2 - emphasis added). But the 1997 Treaty also retained the reference to "any matter of foreign and security policy of general interest" (Article 16).

65 In this respect L. Tindemans, 'En guise d'introduction: considérations personelles sur le Traité de Maastricht', in: J. Monar et al. (Eds.), The Maastricht Treaty on European Union: Legal Complexity and Political Dynamic, Brussels: European Interuniversity Press, 1993, 7-8, who labelled the principle of solidarity as being necessarily complementary to subsidiarity.

66 See, however, on the emerging elements of a Union 'statehood', T. Tiilikainen, 'To Be or Not to Be?: An Analysis of the Legal and Political Elements of Statehood in the EU's External Identity', EFA Rev, 2001, pp. 223-241. 
or the Presidency in CFSP matters to the emerging defence dimension), ${ }^{67}$ the most obvious explicit capacity concerns the treaty-making power of the Union. Article 24 TEU provides:

"When it is necessary to conclude an agreement with one or more States or international organisations in implementation of this Title, the Council, acting unanimously, may authorise the Presidency, assisted by the Commission as appropriate, to open negotiations to that effect. Such agreements shall be concluded by the Council acting unanimously on a recommendation from the Presidency."

It has been argued that such agreements are concluded by the Council not on behalf of the Union but on behalf of the Member States, ${ }^{68}$ but there are even more convincing arguments pointing to a conclusion by the Council of these agreements on behalf of the Union. ${ }^{69}$ The regime of Article 24 and of the connected Declaration No. 4 adopted by the Amsterdam IGC ${ }^{70}$ reflects the multi-level character of the constitution in this regard. Article 24 provides that the Council concludes the international agreements after its members (the Member States) have unanimously agreed that it could do so. ${ }^{71}$ No reference is made to the fact that the Council in concluding the agreement would only act on behalf of the Member States. On the contrary, the second part of Article 24 underlines that the international agreements will be concluded by the Council on behalf of the Union, since it is provided that agreements shall not be binding on a Member State claiming that it has to comply with national constitutional procedures. This provision only makes sense when the Member States themselves do not become a party to the agreement. After all, the question concerning the application of national constitutional procedures would not need to be brought up when the Member States as such would be the parties to the agreement. A contrario, agreements shall be binding on the Union and as Union-law on the Member State that has failed to state that it has to comply with the requirements of its own constitutional procedure. ${ }^{72}$

Declaration No. 4 (on the absence of a transfer of competences) can therefore be understood as a statement to reassure the public in certain Member States that are particularly sensitive to these issues. Declarations - in case of a conflict with Treaty provisions - can never overrule agreements reflected by the Treaty itself. ${ }^{73}$ In any respect, the Declaration in question does not seem to conflict

67 See more extensively Wessel (2000), op. cit., at 533-536.

68 See in particular N. Neuwahl, 'A Partner with a Troubled Personality: EU Treaty-Making in Matters of CFSP and JHA after Amsterdam', EFA Rev., 1998, 177-196; M. Cremona, 'External Relations and External Competence: The Emergence of an Integrated Policy', in Craig and De Búrca (eds), op. cit., 137-175 at 168. Cf. also J.W. de Zwaan, 'Community Dimensions of the Second Pillar' in T. Heukels et al., The European Union after Amsterdam: A Legal Analysis, The Hague: Kluwer Law International, 1998 at 182, who seems to recognise that this is a legal capacity of the Union, but nevertheless denies the existence of a "formal legal personality". Also De Zwaan, 'The Legal Personality of the European Communities and the European Union', NYIL, 1999, 75-113. It has even been argued that Article 24 agreements are 'not legally binding' and not to be viewed as treaties; see the opinion of the Dutch Government in the documents of the Second Chamber, TK 1997-1998, 25922 (R 1613), no. 5, at 51.

69 Without repeating all arguments I refer to Wessel (2000), op. cit., at 527-533.

70 Declaration No. 4 reads: "The Provisions of Article J.14 and K.10 [now Articles 24 and 38 TEU; RAW] of the Treaty on European Union and any agreements resulting from them shall not imply any transfer of competence from the Member States to the European Union".

71 The explicit reference to the unanimity rule (as a lex specialis) seems to exclude the applicability of the general regime of constructive abstention in cases where unanimity is required as foreseen in Article 23 TEU. Furthermore, as indicated by G. Hafner, 'The Amsterdam Treaty and the Treaty-Making Power of the European Union: Some Critical Comments', in: Hafner et al., Liber Amicorum Professor Seidl-Hohenveldern - in Honour of his 80th Birthday, The Hague: Kluwer Law International, 1998 at 279, the application of the constructive abstention to Article 24 would make little sense, since Article 24 already provides the possibility of achieving precisely the same effect insofar as Member States, by referring to their constitutional requirements, are entitled to exclude, in relation to them, the legal effect of agreements concluded by the Council.

72 Ibidem at 276: "[...] the silence of [the] State amounts to an acceptance of the legal effect of the respective treaty with regard to itself already by virtue of Art. 24". See also Pernice (1999), op. cit. at 745: "[...] all indications point to agreements concluded in the name of the Union and not the individual Member States". Cf. also A. Dashwood, 'External Relations Provisions of the Amsterdam Treaty', CML Rev., 1998, 1019 at 1028; and M. Zuleeg, 'Die Organisationsstruktur des Vertrags von Amsterdam', EuR Beiheft 2, 1998, 1515 at 153.

73 Wessel (1999), op. cit., at 37-40. 
with Article 24 TEU. Since the right to conclude treaties is an original power of the Union itself, the treaty-making power of the Member States remains unfettered. The Declaration can only mean that this right of the Union must not be understood as creating new substantive competences for it. ${ }^{74}$

The new Nice Treaty underlines the idea fact that the Council has a competence to conclude treaties on behalf of the Union. According to new paragraphs 2 and 3 of Article 24, the Council shall still act unanimously when the agreement covers an issue for which unanimity is required for the adoption of internal decisions, but it will act by a qualified majority whenever the agreement is envisaged to implement a Joint Action or Common Position. The possibility for the Council to conclude international agreements by a qualified majority further strengthens the idea of a Council that acts as an institution of the EU rather than as a representative of fifteen individual Member States. Finally, a new paragraph 6 sets out that that the agreements concluded by the Council shall also be binding on the institutions of the Union. This explicitly answers the question of whether the Union may have obligations under international law apart from the obligations of the member states.

By now, the Union indeed uses Article 24 as a legal basis for the conclusion of its treaties with third parties. The first treaties were concluded in 2001 and concerned agreements with the Federal Republic of Yugoslavia and Macedonia concerning the activities of the EU observer mission in that country. ${ }^{75}$ Apart from agreements with states, the Union may also engage in a legal relationship with another international organization, as shown by the agreements concluded with NATO on defence cooperation in $2003 .^{76}$

In general one can say that the constitutional division of competence - in terms of vertical powersharing - thus boils down to a system aiming at a single external Union policy through strict procedural rules restricting the freedom of the member states in this area, while at the same time allowing the same member states in the decision-making procedures to prevent exactly this from happening by frequently (but not always) giving them the discretion to judge whether or not issues are fit to be dealt with at the Union level. However, whenever Union decisions do have been taken in the area of foreign and security policy, they bind the member states in the external actions they undertake. This brings us to the question of the effect of these norms within the national legal orders of the member states.

74 As also submitted by Hafner (1998), op. cit., at 272.

75 Agreement between the European Union and the Federal Republic of Yugoslavia, OJ EC L 125, 5.5.2001. The agreement with Macedonia can be found in OJ EC L 241, 11.09.2001.

76 See EU Decision 2003/211/CFSP of 24 February 2003, OJ EU, L 80, 27.3.2003, which includes the text of the Agreement. See further R.A. Wessel, 'The State of Affairs in EU Security and Defence Policy: The Breakthrough in the Treaty of Nice', Journal of Conflict \& Security Law, Autumn 2003 (forthcoming). 


\section{C. (Direct) Effect of CFSP Norms in National Legal Systems}

It remains important to note that the unity of the legal orders of states and international organisations in terms of the validity relations of the norms, only tells us something about the existence of the norms within the respective orders. Hence, so far I have only focussed on one dimension of the multi-level constitution: its existence can be assumed on the basis of the unity of the legal system of which the 'two levels' form a part. At the same time it is underlined that the term 'levels' is not meant to present the relationship between states and international organisations in an hierarchical fashion. On the contrary, the point I tried to make was that it makes more sense to view states and international organisations (once the latter are established) as 'living apart together', but at least side by side within the overall supranational legal order ("Daher ist die Völkerrechtsgemeinschaft die alle positivrechtlichen gemeinschaften überspannende Rechtseinheit, die, gleich einer Kuppel, den ganzen großen Rechtsbau überwölbt"). ${ }^{77}$

The other dimension of the multi-level constitution concerns the effect of norms created by the international organisation within the legal order of the member states. As claimed earlier, this dimension arguably introduces another element underlying the concept of 'constitution' since it brings in other legal subjects than just the states that established the organisation. Does the fact that norms of an international organisation are valid in national legal orders as well (once it is established that they both are part of the same higher legal order), imply that norms created by international organisations are at least theoretically by definition supreme to national norms? The question should be in the negative. Supremacy should not be equated with validity; on the basis of the considerations concerning validity nothing of value can be said regarding the supremacy of norms in one legal order over norms in another legal order. The two questions are of a different nature and should not be confused. ${ }^{78}$ Different norms may have the same validity source and still be conflicting and norms in 'higher' legal orders do not necessarily overrule norms in 'lower' orders. The only way of settling the supremacy-relation between norms of different legal sub-systems (like states and international organisations) is by introducing (or recognising) either a norm in the overarching supranational legal order (e.g. 'individual citizens are responsible for violations of international humanitarian law') or by agreeing on a certain modus in an international agreement between states or in the constituent treaty of an international organisation (e.g. art. 103 UN Charter). Again on the basis of the pacta sunt servanda-rule this modus would take priority over national norms. ${ }^{79}$

Thus, while validity is a prerequisite, rules in the legal order of either the member state or the international organisation may provide for norms to be applied in relation to certain legal subjects only (e.g. EC Directives) or only after a transformation into national law. The notion of direct effect may be distinguished from this applicability in that it only becomes relevant when norms do not have the effect they purport to have and citizens wish to invoke a norm before a national judge. Even if a norm is directly applicable - in the sense that it has a function between the legal subjects within a national legal order - there may be reasons not to allow individuals to invoke it in a court of law. One of the dimensions of the multi-level constitution in the area of foreign policy would be that it regulates the way in which the norms that are created on the EU level would have an effect on the level of the member states.

This means that we have to look for clues in either the international order, the national legal orders, or the EU legal order indicating the direct applicability, the direct effect and the hierarchical status of CFSP norms. General international law, obviously, is silent about this issue and doctrine generally reflects the principle that states are free to decide on how they want to give effect to international law in their national legal orders. ${ }^{80}$ The constitutions of the fifteen EU member states indeed differ in this respect. But, as became clear form the development of the European Community, this issue can authoritatively be settled by norms in the supranational order of an international

\footnotetext{
Verdross (1926), op. cit., at 9.

See in particular on the importance of a division between the different possible relations between legal orders: Werner (1995), op. cit., at 156-159.

Curtin and Dekker (2002), op. cit.

See for instance A. Cassese, International Law, Oxford University Press, 2001, Chapter 8.
} 
organisation. The principles of direct applicability, direct effect and supremacy were recognised by the European Court of Justice (ECJ) as forming part of the 'new legal order' (or in the terms of this paper: the new constitution) regulating the relationship between the EC and its member states, as well as with the legal subjects within the states (natural and legal persons).

Unlike the EC, the non-Community parts of the Union largely fall outside the reach of the ECJ. This means that, for the time being, we cannot rely on authoritative interpretations of the Court regarding the status of CFSP norms in the national legal orders. However, the Treaty itself is not completely silent in this respect. In a recent study, Curtin and Dekker claim that, in principle, Union law is directly applicable in the national legal orders of the member states. ${ }^{81}$ They base this conclusion on the fact that with regard to the new types of EU decisions introduced by the Amsterdam Treaty, the 'framework decisions' and 'decisions', the Treaty explicitly provides that they "shall not entail direct effect" (Art. 34 TEU). This provision would only make sense when these types of decision could in principle have direct effect. Irrespective of the inherent danger in using a contrario arguments, it's acceptance would provide an argument in favour of the direct applicability of EU norms in general, since exclusion of direct effect becomes relevant only in case of direct applicability.

Although this example is drawn from the provision of police and judicial cooperation and not from the provisions of foreign and security policy, there is no compelling reason to differentiate between the two substantive Union areas in this respect. The direct applicability of CFSP norms would then result in the possibility - and even the necessity - of using these norms in the relationships between all legal subjects within the national legal order. Administrative as well as judicial organs could invoke them, but the same holds true for citizens and companies in their mutual relations. This is not to say that all norms by definition could be invoked in national court proceedings. Just as with Community norms, this would depend on the nature of the norm (sufficiently clear and precise), which in this case would ultimately be decided by the national judge. Curtin and Dekker claim that Union norms, at least, could have an 'indirect effect', meaning that "all national authorities have the obligation to interpret national legislation and other measures as much as possible in the light of the wording and purpose of valid Union law". ${ }^{82}$ This, however, implies an acceptance of the supremacy of Union law over national law. After all, 'indirect effect' only becomes relevant in case of a (possible) conflict between an EU and a national norm. Curtin and Dekker, more or less implicitly, base this supremacy on the principle of loyalty, as laid down in article $10 \mathrm{EC}$ as one of the leading principles in the constitution of the Union entailing an obligation for national authorities to interpret national law as much as possible in conformity with these decisions (only limited by the restrictions imposed by the ECJ regarding the application of the principle of indirect effect ${ }^{83}$ ).

It is probably too early to come with definite statements like these regarding the effect of CFSP norms in the national legal orders. Nevertheless, a direct applicability in the more limited definition presented earlier (using the norms in the relationships between all legal subjects within the national legal order) seems to follow from all of the above assumptions. However, it is generally held that CFSP decisions are not directly effective, in the sense that they may be relied upon by national courts. ${ }^{84}$ It is indeed difficult to find provisions in the CFSP decisions containing rights and/or obligations for individuals. This is not to say that individuals cannot be affected at all by CFSP decisions. Despite the fact that practice has not yet called for conclusive statements in this respect, there are no reasons to exclude the direct effectiveness of CFSP decisions in general. Regardless of the undetermined status of CFSP provisions in the Treaty on European Union, national constitutional systems may offer national courts the opportunity to allow individuals to invoke directly effective provisions in cases brought before them. Thus, the Dutch Constitution, for instance, provides in Article 93 that provisions in treaties or in decisions of international organisations have binding force in the Dutch legal order when they are directly effective. The latter question is decided upon by the judge.

81 Curtin and Dekker (2002), op. cit., at 11

82 Ibidem at 11. See on the principle of indirect effect for instance G. Betlem, 'The Principle of Indirect Effect of Community Law', ERPL, 1995, 1.

83 In particular the principle of non-retroactivity of criminal liability. See for instance P. Craig and G. De Búrca, Eu Law, Oxford University Press, 1998, 198-210.

84 See for instance D. Curtin and R.H. van Ooik, 'Een Hof van Justitie van de Europese Unie?', SEW, 1999, No. $1,24-38$ at $30-31$. 
Examples of potentially directly effective provisions may be found in the sanction decisions, although the actual obligations in these cases are mostly laid down in Community Regulations (which may be invoked by individuals on the basis of the EC rules on direct effect). Some CFSP decisions imposing sanctions, however, do not require a follow-up in the form of an EC Regulation, such as the decisions to impose an arms embargo on Afghanistan, Burma/Myanmar, Nigeria or Sudan. ${ }^{85}$ In these cases it would be the CFSP decision itself that would need to be invoked before a national judge. The same holds true regarding CFSP decisions establishing criteria or exceptions with respect to sanctions imposed on third countries. Common Position 95/544/CFSP, for instance, provided inter alia for an interruption of all contacts with Nigeria in the field of sports through denial of visas to official delegations and national teams. Unlike other provisions in this Common Provision - which obligate member states to take "in accordance with national law such measures as are appropriate" - this provision does not seem to be in need of national implementation measures. Another example is Council Decision 97/820/CFSP, allowing for member states to make exceptions to the sanctions imposed on Nigeria. On the basis of this decision and subject to certain conditions, member states may derogate from these rules. In addition, a direct consequence for individuals may for instance emerge on the basis of the establishment of the list of dual-use goods through a CFSP decision. ${ }^{86}$ While the actual obligations are to be found in EC Regulation No. $3381 / 94,{ }^{87}$ the decision to include or exclude certain goods is taken by the Council on the basis of Article 14 as a CFSP Joint Action, which may have consequences for the market position of companies in that area.

A last situation in which national courts could become involved in CFSP issues, would arise in cases of an (alleged) liability of member states being brought up. In cases where neither the Communities, nor the European Union could be held liable for decisions taken by the Council in the area of CFSP, third states or individuals will have to turn to the national courts of the member states to seek justice. Situations in this respect could for instance arise whenever member states cause damage in the course of an EU action (like for instance the assistance in Bosnia-Herzegovina, or the administration of the city of Mostar) or when member states are held liable for breaches of an agreement concluded by the Council on the basis of Article 24 TEU.

The main problem, however, is that all decisions imposing sanctions - EC as well as CFSP are normally converted into national legislation. In order to check the direct applicability of CFSP decisions, one would thus need a case in which a single CFSP decision imposed a sanction regime towards a third country, without this regime being converted into national law. Furthermore, we would need a citizen or a company from that third state to challenge the trade or travel restrictions, in which case the company in the EU member state could point to his obligations on the basis of the CFSP decision. Direct applicability only refers to this rightful reference to valid norms and the case is thus not completely incomprehensible. It is not even unthinkable that an national judge would also allow this decision to have direct effect, in the sense that it may play a role in a national court proceeding. The problem, however, seems to be that in cases like this one cannot escape from dealing with the question of supremacy of the CFSP norms over previously established (or maybe even future) national law. The principle of loyalty may prove to be a valuable candidate for a basis of general supremacy of EU law, but at least in the area of foreign policy the multi-level constitution has not yet grown to full stature to settle this issue.

\footnotetext{
85 Common Positions 96/746/CFSP, 96/635/CFSP, 95/515/CFSP, and 94/165/CFSP respectively.

86 See Decision 94/942/CFSP of 19 December 1994 or the subsequent amending decisions.

8719 December 1994, OJ No. L 267, 31.12.94.
} 


\section{The Constitutional Impact of Flexibility}

One of the major issues in the post-enlargement period of the Union will undoubtedly be that of 'flexibility' ${ }^{88}$ As I have defined the multi-level constitution on the basis of the notion of unity of the legal system, the question emerges what the impact of flexible forms of cooperation within this system will be on its unity. ${ }^{89}$ Here, we deal with, what has been called the sovereignty paradox: on the one hand, the member states seem to retain their sovereignty with respect to cooperation in some fields; on the other hand, the member states accept to limit themselves by agreeing on this procedure within the framework of the European Union. ${ }^{90}$ This, paradox is one of the dimensions of the 'schizophrenic' relationship between the EU and its member states referred to above, and forms the source of a question once posed by Jo Shaw: "is there something inherently contradictory in considering constitutionalism in conjunction with flexibility?"191

The multi-level constitution of EU foreign relations, indeed provides for flexible arrangements. The idea of a possible fragmented Union played an important role during the negotiations on the Amsterdam Treaty in 1996/97. The different variations of flexibility were frequently presented as harmful to the Union's unity. Thus concepts like variable geometry, concentric circles, a multiple-speed Europe, or a Europe à la carte all seemed to prelude the end of the Union. While as such these concepts did not make it to the final draft of the Treaty, the development towards a more flexible approach of the cooperation within the European Union is reflected in the modifications to the TEU introduced by the 1997 Amsterdam Treaty, ${ }^{92}$ and further in the Nice Treaty.

Thus, the post-Nice Treaty on European Union as well as the modified EC Treaty provide for a number of general and specific arrangements allowing for forms of flexible cooperation between a limited number of member states. The Treaties contain general clauses on the possibility for further integration between some but not all member states, under the new heading of 'enhanced cooperation'. In addition, new specific examples of flexibility were introduced, in particular with regard to Title IV EC on the free movement of persons, asylum and immigration and the Protocol incorporating the Schengen acquis into the Union's legal system. In some cases these forms of flexible cooperation allow for even further closer cooperation between some members of the already restricted group of member states. ${ }^{93}$ Many view this development as an undesired, but nevertheless unavoidable, solution to problems related to the social-economic and political differences between the EU member states. It is generally expected that this problem will only become more apparent once the Union has completed its proclaimed extension to Central- and Eastern European states.

The concept of 'flexible cooperation' or 'flexibility' in the context of the present contribution concerns the situation in which the fifteen member states do not necessarily participate to the same extent in every policy or activity of the Union. ${ }^{94}$ The Treaty on European Union nowhere explicitly

88 See for recent surveys of the problems in this area B. de Witte, D. Hanf and E. Vos (Eds.), The Many Faces of Differentiation in EU Law, Antwerpen, etc,: Intersentia, 2001; and G. de Búrca and J. Scott (Eds.), Constitutional Change in the EU: From Uniformity to Flexibility?, Oxford, etc.: Hart Publishing, 2000.

89 See for the impact of flexibility on the 'horizontal' unity of the Union: I.F. Dekker and R.A. Wessel, 'The European Union and the Concept of Flexibility: Proliferation of Legal Systems within International Organizations', in: N.M. Blokker and H.G. Schermers (eds.), Proliferation of International Organizations, The Hague: Kluwer Law International, 2001, pp. 381-414. See in general on flexibility and constitutions: A. Schrauwen (ed.), Flexibility in Constitutions: Forms of Closer Cooperation in Federal and Non-Federal Settings, Groningen: Europa Law Publishing, 2002.

90 See M.H.M. de Bonth, 'Sovereignty Revisited', in: Schrauwen, op. cit., 99-105, at 101. De Bonth develops the argument that the member states have not lost their sovereignty by creating the European Union. Sovereignty is indivisible and is more than just the sum of sovereign rights. The member states have been able to construct the European Union because they are sovereign states.

91 J. Shaw, 'Relating Constitutionalism and Flexibility in the European Union', in De Búrca and Scott (2000), op. cit., pp. 337-358.

92 See Editorial, 'The Treaty of Amsterdam: Neither a Bang nor a Whimper', CML Rev., 1997 at 768.

93 See article 1 of the Schengen Protocol, authorising the signatories to the Schengen agreements to establish closer cooperation among themselves within the scope of the Schengen acquis. See also E. Wagner, 'The Integration of Schengen into the Framework of the European Union', LIEE, 1998, 1-60 at 33.

94 Cf. J.A. Usher, 'Flexibility: The Amsterdam Provisions', in: T. Heukels, et al. (1999), op. cit., at 253. 
refers to the notion of flexibility. ${ }^{95}$ However, one can distinguish between at least two broad categories of flexibility within the Unions' legal system. The first category contains the general enabling clauses on the basis of which the Council has a competence - through the adoption of secondary legislation to decide on the establishment of 'enhanced cooperation'. The second category harbours a variety of forms of flexible cooperation linked to specific fields of EU/EC competence, including the so-called pre-determined forms of flexibility, i.e. forms of differential treatment of certain member states as laid down in the treaties themselves or in protocols. Pre-determined flexibility may either take the form of a permission granted by all member states to a group of member states to act together through Union institutions and legislation (e.g. the Social Protocol under the Maastricht regime), or it is reflected in the permission given to member states not to participate in an activity in which they should in principle participate as a matter of Union or Community law (e.g. the 1991 Protocols on the basis of which Denmark and the United Kingdom are not obliged to take part in the third phase of the EMU; the 1991 Protocol concerning Denmark's non-participation in the elaboration or implementation of measures having defence implications). ${ }^{96}$

Article 43 TEU states: "Member states which intend to establish enhanced cooperation between themselves may make use of the institutions, procedures and mechanisms laid down by this Treaty and the Treaty establishing the European Community [...]". Additional criteria may be found in Article 11 TEC and Article 40 TEU (on police and judicial cooperation). ${ }^{97}$ A new Article 27A was inserted, which explicitly brings the possibility of 'enhanced cooperation' into the realm of CFSP as well.

It is interesting to note the 'constitutional' restrictions which will govern the new regime of enhanced cooperation in the area of foreign and security policy (military and defence policy is excluded by Article 27B) . Article 27A provides that enhanced cooperation in this area "shall be aimed at safeguarding the values and serving the interests of the Union as a whole by asserting its identity as a coherent force on the international scene." Thus, it shall respect "the principles, objectives, general guidelines and consistency of the common foreign and security policy and the decisions taken within the framework of that policy; the powers of the European Community; and consistency between all the Union's policies and its external activities". This preoccupation with 'consistency' returns in the procedure to establish enhanced cooperation. According to Article $27 \mathrm{c}$ member states may address the Council with a request, which will subsequently be forwarded to the Commission and the European Parliament for information. The Commission shall give its opinion particularly on whether the enhanced cooperation proposed is consistent with Union policies. This idea is strengthened by other criteria in Article 43: enhanced cooperation should be aimed at furthering the objectives of the Union and of the Community, at protecting and serving their interests and at reinforcing their progress of integration; it should respect the Treaties and the single institutional framework as well as the acquis communautaire; it may not undermine the internal market or the economic or social cohesion. Article $43 \mathrm{~A}$ adds that enhanced cooperation may be undertaken only as a last resort, when it has been established within the Council that the objectives of such cooperation cannot be attained within a reasonable period by applying the relevant provisions of the Treaties.

Consistency in its more vertical dimension, returns in the provision that an established form of enhanced cooperation is open to all member states, and that both the Commission and the participating member states shall ensure that as many member states as possible are encouraged to take part (Art. 43B). This may form an incentive for participating states not completely to neglect nonparticipants. But the national dimension of the multi-level constitution is also not entirely disregarded:

95 See G. Edwards and E. Philippart, 'Flexibility and the Treaty of Amsterdam: Europe's New Byzantium?', CELS Occasional Paper, no. 3, Cambridge, 1997, at 12: "During the legal and linguistic revision of the text agreed in June (1997), the word 'flexibility' disappeared. The need for it was no longer important in the domestic politics of the UK." See also J. Shaw, 'The Treaty of Amsterdam: Challenges of Flexibility and Legitimacy', ELJ 1998, at 69.

96 Cf. Usher (1999), op. cit., at 254-256.

97 G. Gaja, 'How Flexible is Flexibility under the Amsterdam Treaty?', CML Rev., 1998, 855-870 at 856 ; H. Kortenberg, 'Closer Cooperation in the Treaty of Amsterdam', CML Rev., 1998, 833-854 at 844; C.D. Ehlermann, 'Differentiation, Flexibility, Closer Cooperation:The New Provisions of the Amsterdam Treaty', ELJ, 1998, 246-270, at 264. 
the Council decides on authorisation of enhance cooperation by a qualified majority vote, unless this is blocked by one member for "important and stated reasons of national policy" in which case the matter may be referred to the European Council for decision by unanimity. Once established, however, it is above all the Union (institutions) that govern the enhanced cooperation.

What is the impact of this new possibility offered by the Nice Treaty on the constitutionalisation of foreign and security policy? It is tempting to repeat the conclusion that Ige Dekker and I have reached earlier with regard to forms of flexibility in general within the Union's legal system: the strict requirements for establishing and implementing closer cooperation all point in the direction of an existing legal unity and the rules on flexibility strengthen the notion of the unity of the Union's legal system rather than that they weaken it. ${ }^{98}$ The focus on the principle of consistency as a returning notion underlying enhanced cooperation points to a constitutional embedding in the sense that foreign policy no longer exclusively belongs to the realm of EU member state; even initiatives between smaller groups of states will have to be based on procedures laid down in the Treaty - and are even made possible only on the basis of these provisions. This is not to say that this regime is merely laid down on the Union-level of the foreign policy constitution. The 'non-unitary' dimension can be discovered in the ultimate possibility to block the authorisation of enhanced cooperation in the European Council as well as in the fact that acts adopted within the framework of enhanced cooperation shall not form part of the Union acquis (Article 44). In addition, expenditure resulting from implementation of enhanced cooperation, other than administrative costs entailed for the institutions, shall be borne by the participating member states only, unless, all members of the Council, acting unanimously, decide otherwise (Article 44). A final point in this respect concerns the exclusion of enhanced cooperation of matters having military or defence implications (Article 27B). These matters - when one is able to disconnect them from 'security policy' - can thus only be dealt with on either a (single) national or on the Union level.

The flexibility provisions thus reflect the complex constitutional relationship between the Union and its the member states as well as the unity of national and supranational legal orders referred to in the introduction to this paper. As any constitution may provide for flexibility, the latter is not by definition a 'threat' to the first even when it potentially changes the constitution in a material sense. As Kelsen claimed, a revolution (only) occurs when there has been an unconstitutional change of the constitution, i.e. when any amendment of the constitution has not been effected in accordance with existing procedures for amendment. ${ }^{99}$ The multi-level constitution which forms the basis of the current regime of foreign and security policy allows for flexible arrangements, but at the same time it assures that this regime, which was carefully build up over the past thirty years or so, has enough internal safeguards to prevent its own destruction.

\section{Concluding Observations}

For politicians and international relations experts, looking at the Union's foreign and security policy in terms of a constitution would probably be an outrage. Many still see this policy area as purely intergovernmental cooperation between states. Outcomes are based on power politics, rather than on formal legal procedures. However, an international lawyer could argue that the CFSP objectives, as interpreted in the present contribution, imply a clear limitation of the competences of the member states in this area, as they are geared towards a common policy which was to go beyond cooperation on the basis of the Single European Act in the 1980s. Despite the political power games, the same states agreed on a number of rules of the game and even introduced a new player. The Union was given an 'independent' character, through which the sovereign rights of its member states would be preserved vis-à-vis third states. In that sense - and irrespective of the different contexts - the opinion of the European Court of Justice in the leading case of Van Gend en Loos seems to be applicable to

$98 \quad$ See Dekker and Wessel (2001), op. cit., at 408.

99 See Weyland (2002), op. cit., at 24; H. Kelsen, General Theory of Law and State, Cambridge: Harvard University Press, 1945, at 117-118. 
CFSP as well in the sense that it "constitutes a new legal order of international law for the benefit of which the states have limited their sovereign rights, albeit within limited fields".

It is these 'limited fields' in particular that do not seem to be in line with the prima facie broad scope of CFSP. It follows from its purposes that CFSP is not a common policy in the same way as the concept is used in, for instance, the Community's common agricultural policy or the common commercial policy. ${ }^{100}$ Article 11 , stating that CFSP covers all areas of foreign and security policy, is misleading in the sense that it disregards the fact that Title $v$ is only applicable to those parts of foreign and security policy that are not covered by the Community or the Police and Judicial Cooperation in Criminal Matters (PJCC), and that it accepts and even demands an active role for the member states themselves ("support"), alongside the general obligation of the Union to define and implement CFSP.

What follows from the above analysis is that competences regarding the external political relations of the Union and its member states are adjudicated to different levels of government. Just as in most federal constitutions, the central government should predominantly be responsible for the external relations. Irrespective of the substance of the Union's external policy, the procedural arrangements indeed point in this direction. Unlike most federal systems, however, the foreign relations constitution is more flexible in the sense that it makes use of inherent competences for individual or bi-lateral actions.

The consequences of this multi-level concept are perfectly illustrated by the following quotation, which is drawn from Weiler's analysis of the European Political Cooperation in 1985 and which clearly has not lost its validity:

"[...] the descriptive and prescriptive trend of European foreign policy is towards a Europe singing like a choir remembering of course that the choir concept is not meant to replace totally the one voice. Training several different voices to sing in harmony is at the best of times a most difficult task; one should not be surprised if for a long time yet the European choir will often sing out of tune. Even when successful, one should further not forget that a good choir sometimes sings in unison, other times in several voices and occasionally there is even scope for soloists." ${ }^{101}$

However, something has changed since 1985. The score for this European song increasingly demands a performance of the choir as such, not always at the cost of the beauty of individual voices, but with an ever clearer arrangement of their parts in the whole.

\footnotetext{
100 D. Galloway, 'Common Foreign and Security Policy: Intergovernmentalism Donning the Mantle of the Community Method', in: M. Westlake, The Council of the European Union, London: Cartermill, 1995 at 212. 